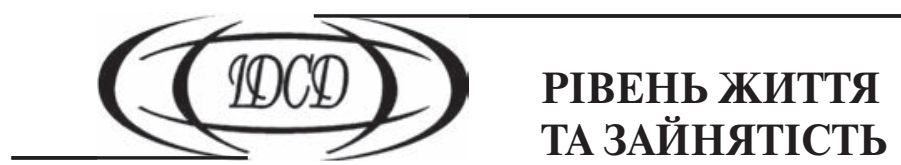

Doi: https://doi.org/10.15407/dse2018.01.126

УДК: $365,330.59(477)$

JEL CLASSIFICATION: I38

\title{
Л.М. ЧЕРЕНЬКО
}

канд. екон. наук, старш. наук. співроб., зав. сектором

Інститут демографії та соціальних досліджень

імені М.В. Птухи НАН України

01032, Україна, м. Київ, бул. Т. Шевченка, 60

E-mail: cherenko@ukr.net

\section{ЖИТЛОВІ УМОВИ НАСЕЛЕННЯ УКРАЇНИ ТА ВИБІР ПРІОРИТЕТНИХ НАПРЯМІВ ЖИТЛОВОЇ ПОЛІТИКИ}

Особливою ознакою України, як і інших країн з радянським минулим, залишаються незадовільні умови проживання населення, перш за все через низькі стандарти забезпеченості житловим простором та незадовільну якість житлових приміщень. Незважаючи на позитивну динаміку щодо середніх показників житлової площі та кількості кімнат на особу, Україна має значно вищі у порівнянні з країнами СС рівні перенаселеності житлових приміщень, особливо коли йдеться про сім'ї, де є двоє та більше дітей. Спостерігається стабільне підвищення рівня комфортності помешкань, проте динаміка обладнання житла базовими зручностями демонструє надзвичайно низькі темпи, за збереження яких не варто очікувати на суттеві зміни в найближчій перспективі. При цьому українці досить позитивно оцінюють свої житлові умови, навіть у роки найбільщого загострення кризових явищ спостерігається стабільне підвищення частки задоволених своїм помешканням. Такі суб'єктивні оцінки можуть свідчити як про значне розшарування за житловими умовами, так і про викривлене сприйняття стандартів нормального житла.

Виникає питання, наскільки активно населення налаштоване на здійснення змін власними силами, якою мірою сьогодні державна політика має впливати на ці процеси та якими мають бути пріоритети політики. Мета статті - розглянути стандарти житлових умов в контексті розуміння населенням задовільних умов проживання та прагнення до їх покращення. Від того, наскільки розвиток житлових умов пояснюється об'єктивними обмеженнями на рівні домогосподарств, насамперед фінансовими, $а$ наскільки - суб'єктивним розумінням базових потреб, залежктть швидкість змін укількісних та якісних параметрах житлових приміщень і територій, які мають безпосереднє відношення до комфортних умов проживання. I саме це має сьогодні визначати пріоритетні напрями житлової політики в Україні.

Ключові слова: житлові умови, стандарти умов проживання, перенаселеність житла, базові зручності, комфортність житла, пріоритетні напрями житлової політики. 


\section{Л.Н. Черенько}

канд. экон. наук, старш. науч. сотр., зав. сектором

Институт демографии та социальных исследований

им. М.В. Птухи НАН Украины

01032, Украина, г. Киев, бул. Т. Шевченко, 60

E-mail: cherenko@ukr.net

\section{ЖИЛИЩНЫЕ УСЛОВИЯ НАСЕЛЕНИЯ УКРАИНЫ И ВЫБОР ПРИОРИТЕТНЫХ НАПРАВЛЕНИЙ ЖИЛИЩНОЙ ПОЛИТИКИ}

Особым признаком Украины, как и других стран с советским прошлым, остаются неудовлетворительные условия проживания населения, прежде всего из-за низких стандартов обеспеченности жилым пространством и неудовлетворительного качества жилых помещений. Несмотря на положительную динамику средних показателей жилой площади и количества комнат на человека, а также оборудования жилья базовыми удобствами, Украина имеет значительно более высокий по сравнению со странами ЕС уровень перенаселенности жилых помещений, особенно когда речь идет о семьях, в которых двое и более детей. Наблюдается стабильное повышение уровня комфортности жилья, однако динамика оснащения базовыми удобствами демонстрирует чрезвычайно низкие темпы, в случае сохранения которых не стоит ожидать существенных изменений в ближайшей перспективе. При этом украинцы довольно позитивно оценивают свои жсилищные условия, даже в годы наибольшего обострения кризисных явлений наблюдается стабильное повышение доли удовлетворенных своим жильем. Такие субъективные оценки могут свидетельствовать как о значительном расслоении по жилищным условиям, так и об искаженном восприятии стандартов нормального жилья. Возникает вопрос, насколько активно население настроено на осуществление изменений собственными силами, в какой мере сегодня государственная политика должна влиять на эти процессы и какими должны быть приоритеты политики. Цель статьи - рассмотреть стандарты жилищных условий в контексте понимания населением удовлетворительных условий проживания и стремления их улучшить. От того, насколько развитие жилищных условий оббясняется объективными ограничениями на уровне домохозяйств, прежде всего финансовыми, а насколько - суббективным пониманием базовых потребностей, зависит скорость изменений в количественных и качественных параметрах жилых помещений и территорий, которые имеют непосредственное отношение к комфортным условиям проживания. И именно это сегодня должно определять приоритетные направления жилищной политики в Украине.

Ключевые слова: жилищные условия, стандарты условий проживання, перенаселенность жилья, базовые удобства, комфортность жилья, приоритетные направления жилищной политики.

\section{L.M. Cherenko}

$\mathrm{PhD}$ (Economics), Head of Sector

Ptoukha Institute for Demography and Social Studies

of the National Academy of Sciences of Ukraine,

01032, Ukraine, Kyiv, blvd Taras Shevchenko, 60

E-mail: cherenko@ukr.net

\section{HOUSING CONDITIONS IN UKRAINE AND CHOICE OF POLICY PRIORITIES}

Afeature of Ukraine, as well as other countries with the Soviet past, is the continuing unsatisfactory living conditions of the population, first of all, due to low standards of living space and unsatisfactory quality of residential premises. Despite the positive dynamics of the average residential space and number of rooms and housing equipment as basic amenities, Ukraine has considerably higher levels of overcrowding in residential areas, especially when it comes to families with two or more children. There is a steady increase in the level of comfort of dwellings, but the dynamics of housing equipment with basic amenities is extremely slow, which if preserved should not be expected to undergo significant changes in the short term. At the same time, Ukrainians are very positive about their housing conditions, even in the years of the greatest aggravation of crisis phenomena there is a steady increase in the share of those satisfied with their homes. Such subjective assessments may indicate both a significant stratification of living conditions and distorted perceptions of normal housing standards. The question arises as to how actively the population is determined to make changes on its own, to what extent today's state policy should influence these processes and what policy priorities should be. This article aims to consider living standards in the context of satisfactory living conditions for the population and the desire to improve them. The extent of the development 
of housing conditions is explained by objective restrictions at the household level, primarily financial, and as far as the subjective understanding of basic needs, depends on the speed of changes in quantitative and qualitative parameters of residential premises and territories that are directly related to comfortable living conditions. And this is what today should determine the priority areas of housing policy in Ukraine.

Keywords: housing conditions, standards of living conditions, overpopulation of housing, basic conveniences, housing comfort, priority directions of housing policy.

Постановка проблеми. Україна помітно відстала від країн СС за кількісними та якісними стандартами житлових умов. Така ситуація стала звичною для населення, адже ми мали помітне відставання за показниками забезпеченості житлом та обладнання його зручностями ще за радянських часів, і програвали не лише розвинутим країнам, але й країнам соціалістичного табору. В умовах перманентної економічної кризи житлова проблема починає відступати на другий план, бо нагальними стають інші життєві потреби, які вимагають першочергового вирішення. Проте подальше ігнорування проблеми і відмова від розроблення цілеспрямованої стратегії іiї вирішення все більше віддаляє нас від перспективи забезпечення належних житлових умов, що спричиняє низку негативних соціальних та економічних наслідків.

Аналіз останніх публікацій. Традиційно в соціальних дослідженнях житлові умови розглядають як складову якості життя чи добробуту населення (О.В. Макарова (O.V. Makarova) [1], О.П. Ковалевська (O.P. Kovalevska) [2] та ін.) або як ознаку бідності чи позбавлення населення нормальних умов життя (В.C. Шишкін (V.S. Shishkin) [3], В.M. Жеребін (V.M. Zherebin) [4] та ін.). Проблему житлових умов розглядають і фахівці суміжних галузей знань - відомі дослідження архітектури житлових будівель, оцінки стану житлового фонду та його кількісного співвідношення з населенням країни, питання стану інфраструктури, насамперед, на регіональному рівні, тощо (B.O. Плоский (V.O. Ploskyj) [5], I.I. Романенко (I.I. Romanenko) [6], B.В. Чернявський (V.V. Cherniavs'kyj) [7] та ін.). Зазвичай житлові умови стають предметом наукових досліджень у країнах пострадянського простору, де існують значні масштаби незадовільних умов проживання, а державна політика постійно стикається з невирішеним завданням забезпечення окремих категорій населення житлом та відновлення аварійних приміщень чи застарілої інфраструктури.

Дана стаття на відміну від попередніх досліджень має на меті зосередитися на стандартах житлових умов не лише з огляду на кількісні та якісні показники житла, а і в контексті розуміння населенням задовільних житлових умов та прагнення до їх покращення. Від того, наскільки розвиток житлових умов пояснюється об'єктивними обмеженнями на рівні домогосподарств, насамперед фінансовими, а наскільки - суб'єктивним розумінням базових потреб та стандартів комфортного житла, має залежати вибір пріоритетних напрямів житлової політики. В свою чергу, правильно обрані пріоритети визначають швидкість змін у кількісних та якісних параметрах житлових приміщень і тих територій, які безпосередньо відносяться до комфортних умов проживання.

Новизна підходу полягає у виборі пріоритетних напрямів житлової політики на основі врахування поведінкової компоненти, з метою досягнення бажаних результатів у більш короткі терміни.

Викладення основного матеріалу. Проблема гарантування населенню країни житлових умов відповідно до державних стандартів проходить червоною лінією крізь події нової історії. Суттєві обсяги введення в експлуатацію житлових приміщень за радянської доби не встигали за розширеним відтворенням населення, 
збільшенням міграційних потоків із сільської місцевості у міста, а також за змінами уявлень про комфортність житла, модель сім’і та трансформаціями традицій спільного проживання. Сучасна демографічна ситуація свідчить про постійне зменшення загальної чисельності населення, що автоматично призводить до зростання кількісних характеристик житлового фонду у розрахунку на одного мешканця, навіть за умови ігнорування аварійних та вчасно невідновлених споруд. Так, у 1990 р. на одного жителя припадало 17,8 м² $^{2}$ а загальний житловий фонд становив 922 млн м², у 2013 р. показники зросли до 23,8 м² та 1097 млн м² відповідно, а у 2016 р., навіть без урахування тимчасово окупованих територій та частини зони проведення АТО, на одну особу припадає 23,1 м², а житловий фонд збільшився порівняно з початком 1990-х років на 56 млн м². Здавалось би, принаймні за кількісними характеристиками житла Україна мала б найближчим часом знайти «точку рівноваги», коли переважна більшість сімей буде забезпечена достатнім житловим простором, і основна проблема буде лежати виключно у площині покращення якості житлових приміщень. Проте насправді розвиток житлових умов упродовж років незалежності супроводжувався поглибленням нерівності.

По-перше, роздержавлення житлового фонду та розшарування населення за доходами призвели до посилення нерівності в розподілі та перерозподілі житла. Негативні прояви нерівності, обумовлені об’єктивною дією ринкових механізмів, обтяжуються через недосконале законодавство та відсутність цілеспрямованої державної політики. Так, сім’ї, які наважуються на народження другої дитини та наступних, переважно опиняються у ситуації обмеженого житлового приміщення, адже покращення житлових умов потребує значних коштів, яких молоді сім’ї, особливо з двома дітьми та більше, просто не мають. Натомість, звичним явищем стають напівспорожнілі житлові приміщення, в яких мешкають самотні пенсіонери, або повністю спорожнілі оселі, які залишаються у спадок та в кращому випадку здаються в оренду, а частіше тримаються про всяк випадок для майбутнього покоління.

По-друге, перманентна економічна криза прискорила процес урбанізації, залишаючи непотрібною частину житлового фонду у економічно непривабливих малих населених пунктах, і в той же час збільшуючи навантаження на житловий фонд великих міст.

Суттєве зростання вартості житлово-комунальних послуг та відповідно зростання фінансового тягаря за утримання понаднормового або зайвого житла має справити позитивний вплив як на ринок нерухомості та ціни на вторинному ринку, так і на ефективність використання житлових приміщень. Проте, для більшості сімей навіть за такого сценарію покращення житлових умов залишиться недоступним, оскільки стандарти оплати праці все ще є неспівставними з вартістю купівлі або оренди житла, особливо у великих містах.

Результатом дії цих чинників став зависокий показник перенаселеності житлових приміщень, який становив у 2016 році 53,9\%, тобто більше половини населення країни мешкало у перенаселеному житлі. Рівень перенаселеності, розрахований за методологією $\mathrm{CC}(E U S I L C)^{1}$, в Україні є найвищим серед європейських країн. Навіть колишні країни соцтабору мають показники у межах 40 \%, окрім Румунії, яка за цим показником не надто відірвалася від України (49,7 \%) (рис. 1).

\footnotetext{
1 Домогосподарство, що не має у своєму розпорядженні мінімум необхідних кімнат: одна спільна кімната для всіх членів; одна кімната для сімейної пари; одна кімната для кожної особи віком 18 років і старше; одна кімната для пари осіб однієї статі у віці від 12 до 17 років; одна кімната для кожної особи віком $12-17$ років, яка не включена до попередньої категорії; одна кімната для пари дітей віком до 12 років.
} 


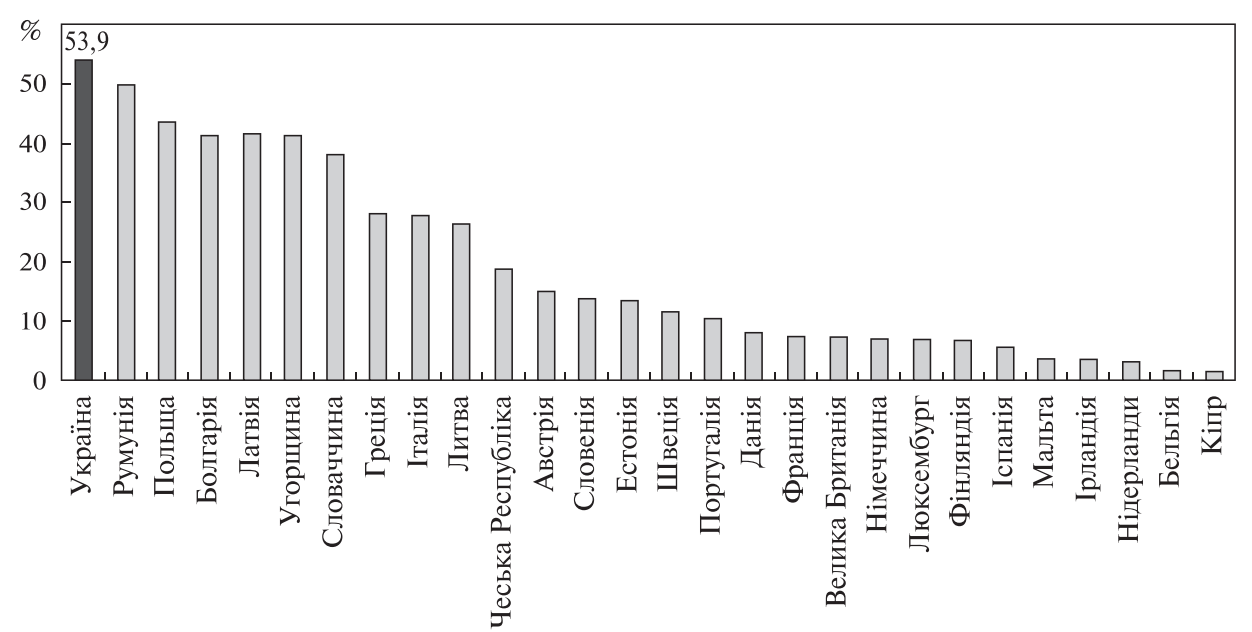

Рис. 1. Частка населення, яке мешкає у перенаселеному житлі, у країнах СС (2015) та в Україні (2016), за методологією EU SILC

Джерело: Державна служба статистики України. URL: http://ukrstat.gov.ua/

Загалом перенаселеність житлових приміщень більше загрожує сім'ям з дітьми - у 2017 році 76,0 \% дітей мешкали у перенаселеному житлі, а у Києві та Львівській області - більше 90 \% дітей. Багатодітні родини взагалі у 95 випадках зі 100 мешкають у перенаселених житлових приміщеннях. Водночас удвічі нижчий за середньоукраїнський рівень перенаселеності мають домогосподарства без дітей, насамперед ті, що складаються з пенсіонерів (27 \%) (рис. 2).

Таким чином, у країні з доволі високими середніми показниками забезпеченості житловим простором переважна більшість дітей мешкає у перенаселених приміщеннях. У такій ситуації покладатися виключно на ринкові механізми і очікувати розв'язання житлової проблеми власними силами родини не видається можливим. Більше того, подальше ігнорування проблеми буде створювати додаткові обмеження для родин, які мали бажання народити більше дітей, що посилюватиме негативні демографічні процеси.

Природно, що нижчі показники перенаселеності спостерігаються у сільській місцевості порівняно з містами, особливо з великими містами (48,9\% у селах проти 63,1 \% у містах). Ця різниця виникає переважно за рахунок домогосподарств без дітей, а багатодітні родини в однаковій мірі обмежені житловим простором, незалежно від місцевості проживання (рис. 2). Такі дані свідчать про нагальну потребу у державному сприянні сім'ям з дітьми, насамперед багатодітним, у покращенні житлових умов.

Попри існування значних масштабів успадкованого житла, яке розподілялося ще за радянських часів, та недостатню поширеність традицій проживання у орендованому житлі, рівень перенаселеності сьогодні прямо залежить від поточних доходів родини. 3 кожною наступною децильною групою перенаселеність зменшується, і в десятій групі показник в 1,7 рази поступається значенню для першої децильної групи (рис. 2). Тобто населення по мірі зростання статків намагається покращувати свої житлові умови, в тому числі шляхом розширення житлового простору. Проте для $10 \%$ найбагатших рівень перенаселеності зберігається на досить високому рівні (33\% проти, наприклад, 26,4 \% по всьому населенню Литви), що зайвий раз свідчить про невідповідність стандартів оплати праці цінам на ринку нерухомості та оренди житла. 

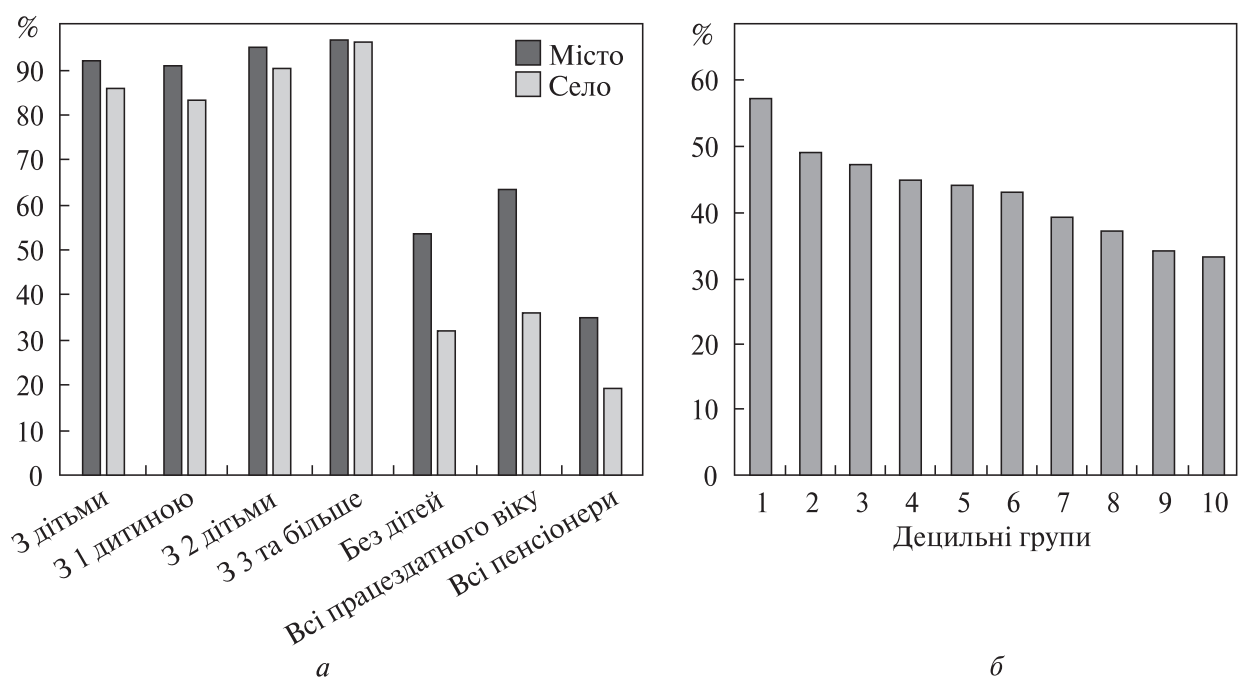

Рис. 2. Частка населення, яке мешкає у перенаселеному житлі, залежно від типів домогосподарства та типу місцевості (a), за децильними групами (б)

Джерело: розрахунки за даними обстежень умов життя домогосподарств Державної служби статистики України.

Перенаселеність житлових приміщень посилюється проблемою їх недостатньої якості - від ознак застарілого та нереставрованого житла до відсутності базових умов комфорту. За даними 2017 р., майже 90 \% житлових приміщень було побудовано до 1990 року, тобто понад чверть століття тому. При цьому у 48 \% квартир та будинків капітальний ремонт ніколи не проводився. Навіть помешкання домогосподарств, збудовані у 1940-х рр., у 20 \% випадків ніколи не підлягали капітальному ремонту. Можна припустити, що значна частина квартир і будинків мають проблеми, які неможна усунути за допомогою періодичного ремонту власними силами.

Комфортність житла у сучасному розумінні передбачає наявність мінімальних базових зручностей - водопроводу та туалету всередині будинку, гарячої води та ванни або душу. Якшо для більшості мешканців міст такі умови стали давно звичними і сприймаються як обов'язкові складові комфорту, то для сільської місцевості 3 технічними і фінансовими проблемами проведення комунікацій та специфікою вікової структури населення забезпечення елементарними зручностями все ще залишається непоширеним явищем. За останні десять років відбулися позитивні зміни показників обладнання житла комунальними зручностями, проте темпи змін є настільки повільними, що свідчать про тривалий процес осучаснення житлових приміщень у майбутньому. Наприклад, частка помешкань, обладнаних водопроводом та каналізацією, зросла з 65-66 \% у 2008 році до 79-80 \% у 2017, а ванною або душем - відповідно з 60 до 65 \%. (рис. 3). Тож не варто розраховувати на прискорення процесів осучаснення житла виключно за рахунок власників квартир та будинків, без комплексних змін у системах комунікацій малих населених пунктів.

Зрозуміло, що у великих містах обладнання водопроводом та каналізацією наближується до $100 \%$, а у малих містах, за даними 2017 р., становить відповідно 87 та $86 \%$. Натомість, у сільській місцевості лише трохи більше половини населення мешкає у комфортному житлі. В сільській місцевості обладнання помешкань водопроводом та каналізацією певною мірою залежить від статків родини: якщо серед 
10 \% найбідніших лише 40 \% обладнані базовими зручностями, серед найбагатшого децилю - майже 70 \%. Якщо змоделювати ситуацію, коли доходи більшості селян наблизяться до рівня найбільш заможних $10 \%$, то за чинних стандартів обладнання житла зручностями не більше двох третин сільських домогосподарств будуть мешкати у комфортному житлі. Отже, лише за рахунок зростання доходів у сільській місцевості неможливо досягти кардинальних зрушень в якісних параметрах житлових умов.

Об’єктивні параметри житлових умов українців призводять здебільшого до негативних висновків як за кількісними, так і за якісними характеристиками житлових приміщень. Постає питання, якою мірою покращення житлових умов може відбутися за рахунок власних ресурсів домогосподарств, а вирішення яких проблем потребує цілеспрямованих дій з боку органів державного управління.

Низькі доходи, звичайно, впливають на темпи покращення житлових умов і стримують зміну уявлень про їх стандарти. Проте, динаміка доходів не може пояснити зміни у прагненнях населення до покращення житлових умов.

У структурі витрат домогосподарств покращення житлових умов посідає чи не останні позиції - складає менше 2 \% грошових витрат домогосподарств України. I якщо у періоди пом'якшення кризових явищ (2010-2011) частка витрат на купівлю нерухомості, капітальний ремонт, будівництво житла та інших будівель досягала 1,4-1,5 \% грошових витрат, то у останні роки вона опустилася до 0,5\%.

Зрозуміло, що в умовах обмеженого бюджету сім’ї основне питання лежить у площині вибору пріоритетів. До того ж, за звуження споживчих можливостей, коли домогосподарство намагається ущільнити свої витрати, подекуди навіть життєво необхідні, питання покращення житлових умов природно відходить на другий план, до кращих часів.

В економічно сприятливих умовах, коли у більшості домогосподарств з'являються умовно вільні кошти після здійснення традиційних та обов’язкових витрат, виникає проблема вибору пріоритетів вищого порядку. І коли питання покращення житлових умов (як за кількісними, так і за якісними параметрами) є одним з пріоритетних для переважної більшості населення країни, то темпи покращення житлових умов в цілому будуть високими, а стандарти житлових умов будуть динамічно змінюватися значно швидше за зміну поколінь.

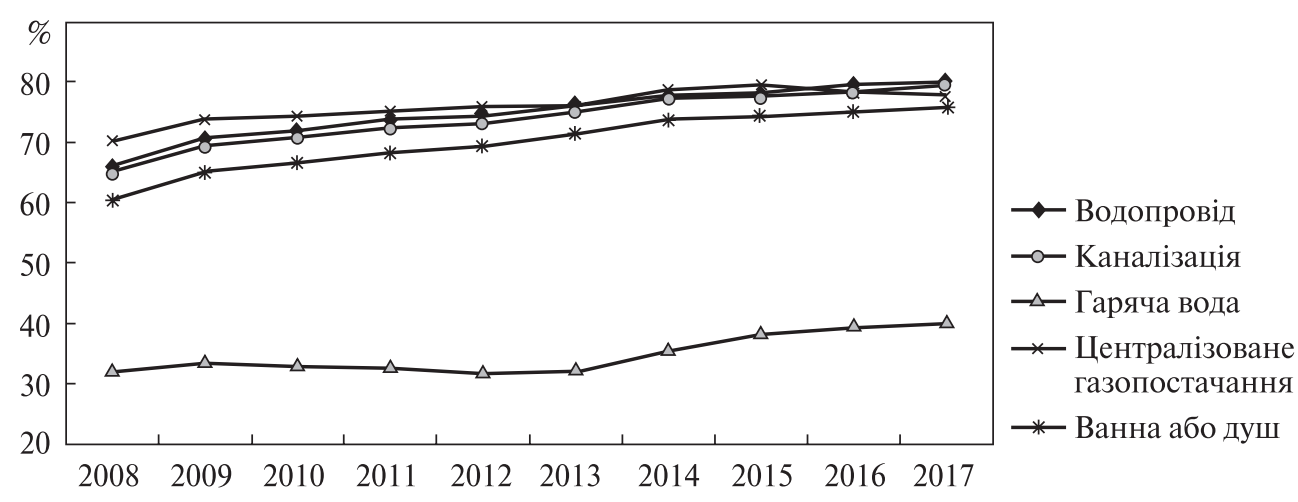

Рис. 3. Питома вага домогосподарств за наявністю в їхньому житлі основних комунальних зручностей, 2008-2017 pp.

Джерело: Державна служба статистики України. URL: http://ukrstat.gov.ua/ 


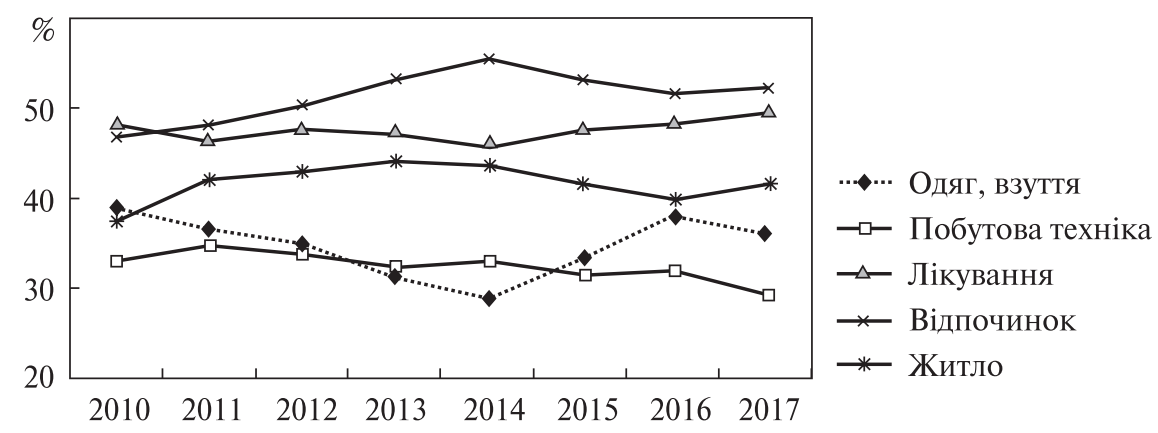

Рис. 4. Частка домогосподарств, які повідомили, що за значного збільшення доходів спрямували б додаткові кошти в першу чергу на такі цілі (п'ять найбільш поширених), у \% за децильними групами Джерело: Державна служба статистики України. URL: http://ukrstat.gov.ua/

Упродовж останнього десятиліття бажання покращити житлові умови впевнено входить до п’ятірки лідерів у системі пріоритетних витрат, і частіше посідає третю за ієрархією позицію. Проте лише за уявної ситуації, коли йдеться про бажані витрати за значного збільшення доходів (рис. 4). Дійсно, у 2010-2017 рр. досить вагомий відсоток населення (35-45 \%) вважали, що спрямували б кошти на житло у разі значного збільшення доходів. Реально ситуація виглядає інакше: впродовж 2013 р., до нового витку кризи, лише 3,8 \% домогосподарств України здійснювали витрати на купівлю нерухомості, будівництво або капітальний ремонт житла, дач, гаражів. При цьому 71,5 \% всіх витрат на купівлю, будівництво та капітальний ремонт житла припадало на найбагатшу (десяту) децильну групу. Решта ж домогосподарств такі витрати здійснювала вкрай рідко, а їх загальний розмір був прямо пропорційним поточним доходам населення.

Виникає питання, чи дійсно у разі покращення економічної ситуації та вагомого зростання доходів переважної більшості населення кожен третій почне спрямовувати кошти на покращення житлових умов. Дійсно, частка витрат на житло у бюджетах сімей та питома вага домогосподарств з такими витратами очікувано буде зростати 3 підвищенням реальних доходів, проте навряд чи охопить третину населення.

Якщо частка домогосподарств з бажаними витратами на одяг, взуття та лікування за значного збільшення доходів помітно зменшуються з кожною наступною децильною групою, а частка охочих витратити кошти на відпочинок збільшується, то по відношенню до витрат на житло показник практично не залежить від рівня достатку родини (рис. 5).

Отже, зі зростанням достатку українців пропорційно зростає потреба у витрачанні додаткових коштів на відпочинок, ймовірніше з міркувань цікавішого проведення дозвілля. Натомість майже пропорційно зменшується необхідність у додаткових витратах на лікування, одяг і взуття, скоріше за все через зменшення обсягів незадоволених потреб у таких товарах та послугах з переходом у чергову доходну групу. На противагу цьому практично незмінним для всіх груп залишається бажання витратити додаткові кошти на житло (лише для десятого децилю частка дешо зростає). 3 одного боку, це свідчить про актуальність потреби в покращенні житлових умов для всіх без винятку доходних груп, а з іншого - про те, що зі зростанням статків не зростає пріоритетність витрат на житло на фоні інших напрямів.

Загалом у системі пріоритетів витрати на житло займають другу за рангом позицію лише у найбагатшій децильній групі, у решти ж - опускаються на третю чи четверту 
позицію. За такого розподілу пріоритетів сподіватися на швидкі зміни в стандартах житлових умов не варто, тим більше за умови повільного зростання купівельної спроможності.

Можливо, причиною недостатнього прагнення населення до покращення житлових умов власними силами є задоволеність наявними умовами, тобто занижені стандарти або уявлення про нормальні стандарти житла. Тому сім’я радше витратить кошти на дорожчий відпочинок, аніж на обладнання чи капітальний ремонт житла.

Дійсно, більшість населення позитивно оцінює свої житлові умови, хоча об’єктивних підстав частіше для цього переважно нема. Частка задоволених своїми житловими умовами зростає навіть у періоди найгостріших кризових проявів останніх років. Загалом за 2005-2017 р. частка задоволених житловими умовами зросла з 43,2 до $55,5 \%$, а частка зовсім незадоволених зменшилася з 21,2 до 14,4 \% (рис. 6).

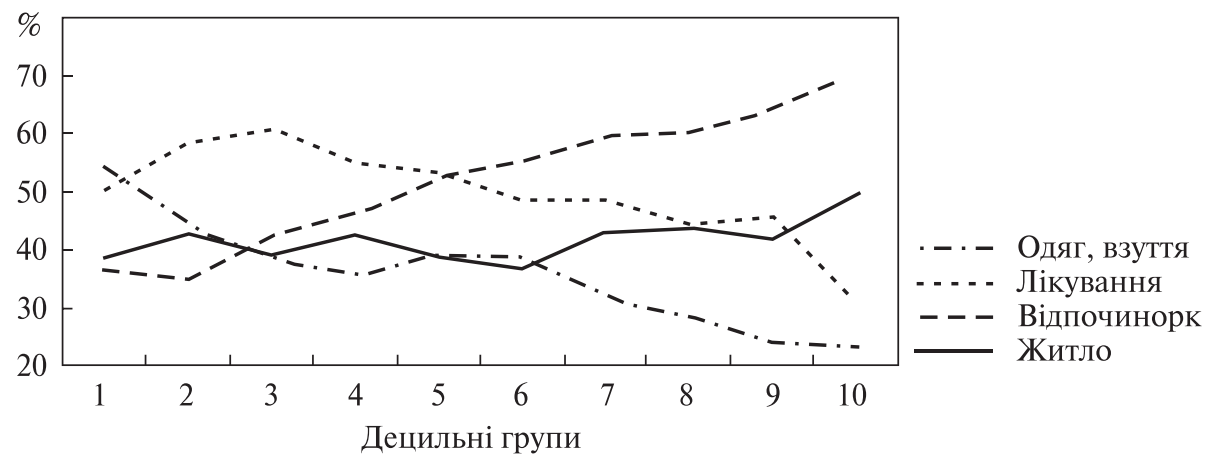

Рис. 5. Частка домогосподарств, які повідомили, що за значного збільшення доходів спрямували б додаткові кошти на такі цілі (чотири найбільш поширених), у \% за децильними групами

Джерело: Державна служба статистики України. URL: http://ukrstat.gov.ua/

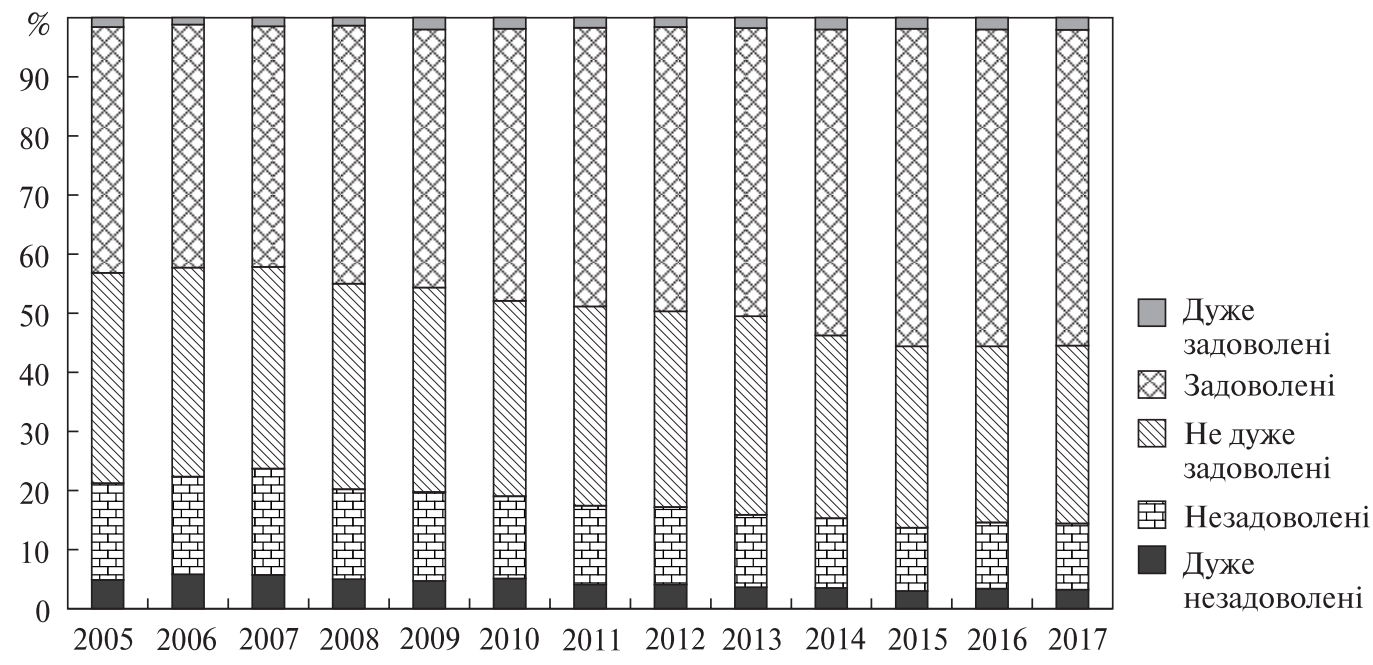

Рис. 6. Розподіл населення за ступенем задоволеності житловими умовами, 2005-2017 pp.

Джерело: Державна служба статистики України. URL: http://ukrstat.gov.ua/ 
При цьому, відсоток задоволених особливо інтенсивно зростає впродовж 2014-2017 р. на фоні загострення соціальних проблем. Частка дуже незадоволених коливається близько $2 \%$, що неспівставно з масштабами аварійного житлового фонду та показниками перенаселеності житлових приміщень.

Аналогічні результати дають інші незалежні опитування: лише $19 \%$ вважають свої житлові умови незадовільними, $44 \%$ - середніми, а $37 \%$ - хорошими. Цілком закономірним виглядає прямий зв'язок між загальною оцінкою свого рівня життя і якості житлових умов. Так, поганими вважають свої житлові умови $6 \%$ тих, хто ототожнює свій рівень життя з забезпеченістю, $26 \%$ - із бідністю і $43 \%$ - зі злиденністю.

Невже українців не обходить проблема комфортного проживання, а базові зручності вони вважають необов'язковими? Дані того ж обстеження Держстату за модулем депривації свідчать, що практично кожен другий сільський мешканець потерпає від відсутності в житлі зручностей, оскільки їх не вдається забезпечити за рахунок власних коштів. Найбільша частка $(50,7$ \%) відчувають позбавлення через відсутність коштів на обладнання туалету зі зливом всередині житла. Цікаво, що інші депривації, пов'язані з браком коштів, не мають настільки виражених поселенських ознак. Отже, зіставлення даних різних анкет з одного вибіркового обстеження може свідчити, що всі сільські мешканці, позбавлені базових зручностей у власному житлі, потерпають від цього.

Тоді як пояснити здебільшого позитивні оцінки власних житлових умов, підтверджені різними незалежними опитуваннями? Зазвичай українці не вирізняються особливим оптимізмом, оцінюючи власні статки чи соціальний статус. Наприклад, у 2016 р. 74 \% домогосподарств віднесли себе до бідних, і ніхто - до заможних. Можна припустити, що обстеження не доохоплює певний відсоток найбільш багатих, а у 2016 р. ще не було помітного зростання доходів після їх суттєвого кількарічного падіння, проте розподіл різних за статками груп відповідно до самооцінки доходів свідчить про вкрай занижені суб’єктивні оцінки. Варто зазначити, що серед 10 \% найбільш забезпечених (за об'єктивними оцінками) майже половина вважає себе бідними, а менше 2 \% відносять себе до середнього класу (рис. 7).

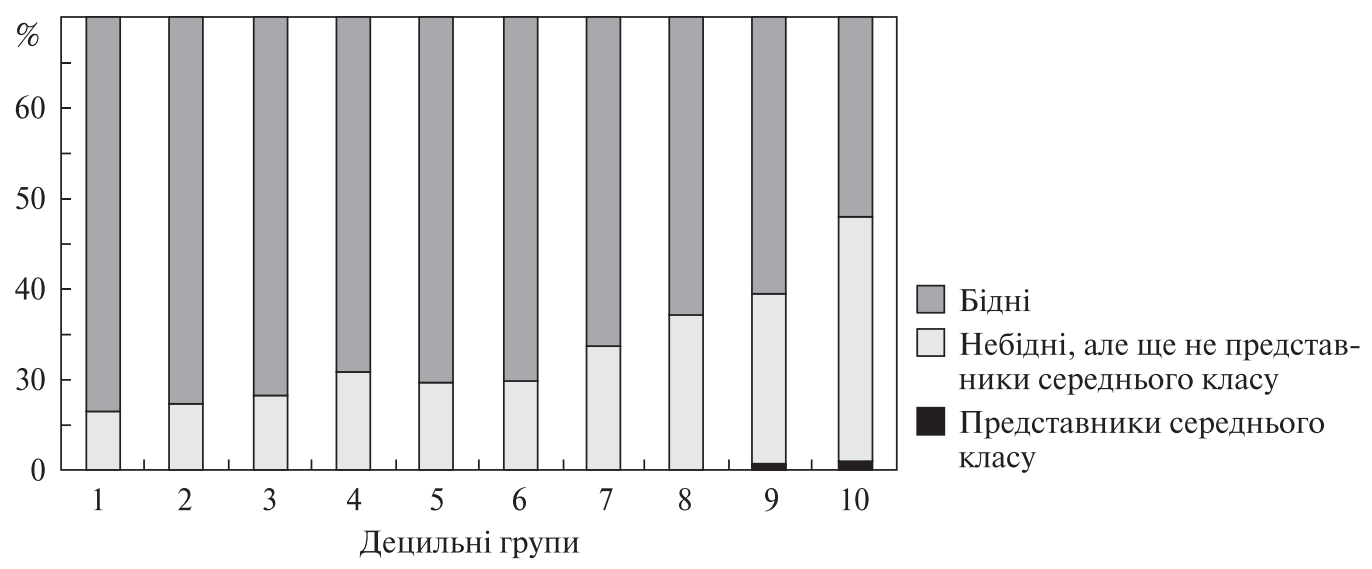

Рис. 7. Розподіл домогосподарств за самооцінкою матеріального добробуту залежно від децильної групи, 2016 р.

Джерело: Державна служба статистики України. URL: http://ukrstat.gov.ua/ 
Отже, населення з украй заниженою самооцінкою свого майнового статусу 3 кожним роком, незважаючи на соціальні негаразди, краще оцінює свої житлові умови. 3 одного боку, більшість задоволена своїми житловими умовами, а з іншого - понад 40 \% населення бажає спрямувати додаткові кошти на покращення свого помешкання. Такі дані можуть опосередковано свідчити про значну диференціацію в забезпеченості житлом з огляду на кількісні та якісні характеристики. 3 іншого боку, може спрацьовувати фактор занижених стандартів житла, успадкованих від радянської доби та поширених переважно серед представників старших вікових груп. Звичка жити в квартирах чи будинках, які не відповідають загально визнаним у цивілізованих державах умовам комфорту, на фоні інколи значно гірших умов проживання знайомих, сусідів, родичів, психологічно налаштовує на заниження стандартів житлових умов у суспільстві.

Виникає питання, що є ключовим фактором, а що наслідком його дії - стандарти житлових умов у суспільстві, насамперед уявлення переважної більшості населення про обов'язкові складові сучасного комфортного помешкання, сприяють просуванню проблеми та розвитку житлових умов, або ж фактичний рівень життя формує стандарти й уявлення про житло. Від відповіді на це питання залежить зміст державної політики, включаючи житлову складову.

Наприклад, якщо визначальним фактором розвитку житлових умов є стандарти, що склалися у суспільстві, і саме вони формують житлові умови майбутнього, то основний акцент політики має зосереджуватися на зміні уявлень, насамперед, серед молодших вікових категорій. Це означає, що державні кошти мають насамперед бути спрямовані на сучасне обладнання шкіл та дитячих садків, дитячих оздоровчих закладів і молодіжних центрів. Молоде покоління в такому випадку усвідомлюватиме необхідність існування сучасних складових комфорту, і намагатиметься слідувати їм у самостійному житті. Кардинальна зміна уявлень про стандарти житла гарантуватиме значний ривок у характеристиках житлових умов за 10-20 років, коли покоління, що нині підростає, буде ставати рушійною силою суспільства. Але невже ми не зможемо досягти стандартів цивілізованих країн раніше?

Якщо визначальним фактором трансформації житлових умов є реальний рівень життя населення, то шлях до сучасних житлових приміщень та обладнаних прибудинкових територій лежить через підвищення доходів та розробку програм обладнання квартир і будинків частково або повністю за державні кошти. Враховуючи сучасну ситуацію з хронічним дефіцитом державних ресурсів та дуже повільним зростанням реальних доходів населення, такий шлях до кардинальних змін житлових умов видається ще довшим.

Зрозуміло, що в реальному житті чинники та наслідки є взаємопов'язаними, а їх тісна взаємодія не дає змоги повністю розділити та оцінити впливи. Проте, моделювання імітованих ситуацій може дати уявлення про те, яких максимальних результатів можна досягти за рахунок окремого чиннику за інших рівних умов.

Як зазначалося вище, максимальний рівень обладнання сільських помешкань водопроводом і каналізацією, якого можна досягти виключно за рахунок зростання доходів населення (за інших незмінних умов), становить $65 \%$. Отже, очікування вищих результатів лише за рахунок підвищення реальних доходів населення в умовах економічного зростання будуть марними, якщо не задіяти додаткові важелі житлової політики, передовсім шляхом сприяння розвитку централізованих мереж комунікацій на рівні громад. Якщо рівень обладнання базовими зручностями сільських помешкань у межах 60-70 \% вважається нормальним для забезпечення базових потреб життя, i 
таким, що не перешкоджає формуванню якісно вищих стандартів житлових умов у нових поколінь, тоді це питання може не розглядатися як пріоритетне для формування стратегічних та програмних документів.

У випадку, коли є політична воля до кардинальних змін у контексті обладнання сільських помешкань, на перший план виходить питання налагодження інфраструктурних комунікацій для спрощення підключення населенням власних будівель до систем життєзабезпечення. При цьому в світлі сучасної екологічної ситуації тут йдеться не лише про питання комфорту, а подекуди про життя та здоров'я людей, адже забезпечення якісною водою іноді стає проблемою навіть для традиційно екологічно благополучних регіонів.

Набагато складнішим питанням є краще забезпечення сімей життєвим простором та зменшення рівня перенаселеності житлових приміщень, насамперед, у великих містах. Зрозуміло, що невідповідність стандартів оплати праці в країні ринковій вартості житла і навіть вартості капітального ремонту помешкання не залишає сумнівів щодо необхідності на даному етапі державного втручання у вирішення проблеми покращення житлових умов, принаймні для соціально вразливих категорій населення та представників соціально важливих професій. Практика надання квартир на безоплатній чи частково безоплатній основі без обов'язкового їх повернення на користь держави, муніципалітету, відомства тощо, не підтверджує свої дієздатності, більше того, свідчить про поширення корупційних схем та неефективне розпорошення державних коштів. Навряд чи посилення відповідальності та контролю у цій сфері принципово змінить ситуацію, і система розподілу житла стане ефективнішою з точки зору забезпечення особливих категорій житлом.

Сьогодні найбільш перспективним видається започаткування процедури створення «банків» орендного житла на базі муніципалітетів чи територіальних громад. Ці процеси є не одномоментними, і можуть розтягнутися на роки, проте вони дають чітке бачення щодо можливості вирішення на справедливих засадах житлової проблеми в майбутньому. Створення мережі муніципального орендного житла не лише пришвидшить процес покращення житлових умов для окремих категорій населення, але й сприятиме швидкому розвитку ринку орендного житла, що в свою чергу призведе до зниження вартості найманих квартир відповідно до платоспроможності працюючого населення. Поширення традицій проживання у орендованому житлі, включаючи довгострокову оренду на муніципальному рівні, створює можливість для швидшого вирішення житлової проблеми та переходу до якісно нових стандартів житлових умов.

Висновки. Це дослідження свідчить, що населення України здебільшого має незадовільні житлові умови, визначені недостатнім житловим простором і, відповідно, високим рівнем перенаселеності помешкань, або відсутністю базових умов комфорту в житлових приміщеннях, насамперед, у сільській місцевості. При цьому населення досить позитивно оцінює свої житлові умови, що не може не дивувати на фоні традиційно вкрай заниженої самооцінки майнових і соціальних статусів. Така ситуація може опосередковано свідчити про значне розшарування населення за житловими умовами. Крім того, виникає гіпотеза, що населення внаслідок тривалого історичного відставання в стандартах житла від розвинених країн має викривлені уявлення щодо задовільних умов проживання.

Ураховуючи сучасну ситуацію щодо розвитку житлових умов, фінансової спроможності та налаштованості населення на їх покращення власними силами, а також виходячи з оцінки перспективних змін у рівні доходів та уявленнях суспільства щодо 
стандартів житла, можна припустити, що розвиток житлових умов у найближчі десятиліття не вийде на новий рівень, а збереже занизькі темпи, які спостерігалися в останні десять років. Таким чином, без перегляду основних складових державної політики та без визначення принципово нових засад і пріоритетних напрямів вирішення житлової проблеми Україна може ще більше віддалитися від європейських стандартів.

Обмеженість державних ресурсів і хронічне недофінансування соціальних програм, націлених на вирішення житлової проблеми, а також низька ефективність реалізації чинних механізмів надання житла на безоплатній чи частково безоплатній основі, свідчить про необхідність визначення нових пріоритетних напрямів житлової політики. Задля зменшення рівня перенаселеності житла необхідно започаткувати створення «банків» муніципального орендного житла для соціально вразливих категорій сімей та представників соціально важливих професій. Комфортність сільських помешкань може вийти на якісно новий рівень завдяки сприянню розвитку мережі комунікацій на рівні громад, а також обладнанню об’єктів соціальної інфраструктури села сучасними зручностями, що змінюватиме загальне уявлення населення про стандарти нормального житла.

\section{ЛІТЕРАТУРА}

1. Макарова О.В. Житлові умови як ключовий аспект якості життя в Україні // Вісник Національної академії наук України. - 2015. - № 6. - С. 28-33.

2. Ковалевська О.П. Житлові умови в системі характеристик якості життя // Державне управління: удосконалення та розвиток. - 2011. - № 3 [Електронний ресурс]. - Режим доступу : http://www. dy.nayka.com.ua/?op=1\&z=475 (дата звернення: 14.03.2018).

3. Шишкін В.С. Бідність населення України за житловими умовами // Демографія та соціальна економіка. - 2016. - № 1 (26). - С. 51-64. - doi: https://doi.org/10.15407/dse2016.01.051.

4. Жеребин В.М., Романов А.Н. Уровень жизни населения. Основные категории, характеристики и методы оценки. - М. : ЮНИТИ-ДАНА, 2002. - 592 с.

5. Плоский В.О., Гетун Г.В. Архітектура будівель та споруд. Книга 2. Житлові будинки: Підручник. - К. : Кондор, 2015. - 617 с.

6. Романенко I.I. Архітектура будівель і споруд. Конспект лекцій навчальної дисципліни. - Харків : ХНАМГ, 2011. - $168 \mathrm{c}$.

7. Чернявський В.В. Архітектура будівель і споруд. Архітектурні конструкції малоповерхових цивільних будівель: навч. посіб. - Полтава : ПолтНТУ, 2001. - 182 с.

8. Ханас $O$. Щастя не в «квадратах»: у Гройсмана розповіли про житлові умови українців // ZNAJ. UA [Електронний ресурс]. - Режим доступу : https://znaj.ua/society/shastya-ne-v-kvadratah-ugrojsmana-rozpovily-pro-zhytlovi-umovy-ukrayinciv (дата звернення: 14.03.2018).

\section{REFERENCES}

1. Makarova, O.V. (2015). Zhytlovi umovy iak kliuchovyj aspekt iakosti zhyttia v Ukraini [Housing conditions as a key aspect of quality of life in Ukraine]. Visnyk Natsional'noi akademii nauk Ukrainy - Visnyk of the National Academy of Sciences of Ukraine, 6, 28-33 [in Ukrainian].

2. Kovalevska, O.P. (2011). Zhytlovi umovy v systemi kharakterystyk iakosti zhyttia [Housing terms in system of descriptions of live quality]. Derzhavne upravlinnia: udoskonalennia ta rozvytok - Public Administration: Improvement and Development, 3. Retrieved from http://www.dy.nayka.com.ua/?op=1\&z=475 [in Ukrainian].

3. Shishkin, V.S. (2016). Bidnist' naselennia za zhytlovymy umovamy [Poverty population in Ukraine by housing conditions]. Demohrafiia ta sotsial'na ekonomika. - Demography and social economy, 1 (26), 51-64. doi: https://doi.org/10.15407/dse2016.01.051 [in Ukrainian].

4. Zherebin, V.M., \& Romanov, A.N. (2002). Uroven' zhizni naselenija. Osnovnye kategorii, harakteristiki i metody ocenki [Standards of living. Main categories, characteristics and methods of assessment]. Moskva : JuNITI-DANA [in Russian]. 
5. Ploskyj, V.O., \& Hetun, H.V. (2015). Arkhitektura budivel' ta sporud. Knyha 2. Zhytlovi budynky [Architecture of buildings and structures. Book 2. Residential Houses]. Kyiv : Kondor [in Ukrainian].

6. Romanenko, I.I. (2011). Arkhitektura budivel' i sporud. Konspekt lektsij navchal'noi dystsypliny [Architecture of buildings and structures. Summary of lectures in the discipline]. Kharkiv : KhNAMH [in Ukrainian].

7. Cherniavs'kyj, V.V. (2001). Arkhitektura budivel' i sporud. Arkhitekturni konstruktsii malopoverkhovykh tsyvil'nykh budivel' [Architecture of buildings and structures. Architectural structures of low-rise civil buildings]. Poltava : PoltNTU [in Ukrainian].

8. Khanas, O. (2018). Schastia ne $\mathrm{v}$ «kvadratakh»: u Hrojsmana rozpovily pro zhytlovi umovy ukraintsiv [Happiness is not in «squares»: Groisman was told about living conditions of Ukrainians]. ZNAJ.UA. Retrieved from https://znaj.ua/society/shastya-ne-v-kvadratah-u-grojsmana-rozpovily-pro-zhytloviumovy-ukrayinciv [in Ukrainian].

Стаття надійшла до редакції журналу 22.02.2018. 